\title{
Commodities Versus Stocks: Analysis of Their Performance from 2009 Through 2015
}

\author{
Monika Krawiec \\ Warsaw University of Life Sciences, Department of Econometrics and \\ Statistics
}

\section{Abstract}

Although over the last several years one could have witnessed unprecedented interest in commodity investments, the view of commodities from an investor's perspective is of more recent date (with the exception of precious metals). There are several reasons for investing in commodities. First of all, they let investors gain equity-like or higher returns. Then, they can help to mitigate risk and improve portfolio diversification. They can also provide a possible hedge against unanticipated inflation. The growing popularity of commodity investing has been followed by a great number of new investment vehicles that make commodity investments available to a wider audience. Thus, investors based on their risk-return criteria and individual requirements may select from a broad range of commodity-linked financial instruments. One of possibilities is investing through a commodity index. This approach is especially attractive to investors that are familiar with investing in stock indexes. In theory, commodity indexes share a similar goal: to create a broad indicator of commodity price movements, though in practice portfolio weightings, construction, and calculation methodology vary significantly from one index to another. The most important of commodity indexes are: the Thomson Reuters/Core Commodity CRB Index, the S\&P Goldman Sachs Commodity Index, the Bloomberg Commodity Index (former Dow-Jones AIG Commodity Index), and the Deutsche Bank Liquid Commodity Index. The present paper is aimed at assessing return and risk characteristics of these indexes and at providing a comparative analysis of their performance in relation to the most important equity indexes, such as S\&P500, FTSE100, CAC40, DAX, WIG, BUX, IBovespa, Nikkei, Shanghai Composite (SSE), TSE300 (current S\&P/TSX Composite Index), and AOI (All Ords). The empirical data covers daily quotations from January 5, 2009 to December 30, 2015. To verify whether the commodity indexes returns differ significantly from the returns of equity indexes, the nonparametric Mann-Whitney test is applied. The test has been chosen as returns of commodity indexes are not normally distributed.

Keywords: commodities, equities, return, risk, Mann-Whitney test 


\section{Introduction}

Although over the last several years one could have witnessed unprecedented interest in commodity investments, the view of commodities from an investor's perspective is of more recent date, with the exception of precious metals which have traditionally been viewed as a store of wealth (Rouwenhorst 2012). There are several reasons for investing in commodities. First of all, academic studies demonstrate longterm viability of commodities as an asset class that produces similar returns to equities with less historical volatility and negative skewness (Gorton and Rouwenhorst 2004, Akey 2005, Proelss and Schweizer 2008, Chevalier and Ielpo 2013). Other research illustrates that commodity returns have been non-correlated to financial assets like stocks and bonds, and that commodities demonstrate inflation hedging properties favorable to stocks and bonds (Greer 2000, Busken 2004, Kat and Oomen 2007, Fabozzi, Füss and Kaiser 2008, Koutsoftas, Ross and Fila 2010). Some studies also find that adding commodities to a traditional stock and bonds portfolio can enhance returns and decrease volatility (Bodie and Rozansky 1980, Anson 2008, You and Daigler 2012, Bessler and Wolff 2015).

The growing popularity of commodity investing has been followed by a great number of new investment vehicles that make commodity investments available to a wider audience. Thus, investors based on their risk-return criteria and individual requirements may select from a broad range of commodity-linked financial instruments. Generally, methods of investing in commodities are divided into direct investments, such as direct purchase of commodities in the cash market or forward contracts, and into indirect investments, e.g. futures contracts and options on futures, commodity-based equities, mutual funds, exchange-traded funds (ETFs), investable commodity indexes (Geman 2007, Schofield 2007, Engelke and Yuen 2008). According to Ackworth (2005), investing through a commodity index is especially attractive to institutional investors that are familiar with index investing in equities world and like the idea of "buying the market" in a single transaction. Most of commodity indexes have publicly traded commodity futures index contracts, which can be purchased and rolled. One may also enter into an over-the-counter (OTC) swap with a counterparty to gain direct participation in these indexes. There are also mutual fund managers who offer funds tied to various indexes by investing in structured notes or swaps that receive the index total return in exchange for paying the Treasury bill component of the index plus fees (Engelke and Yuen 2008).

In theory, commodity indexes share a similar goal: to create a broad indicator of commodity price movements, though in practice portfolio weightings, construction, and calculation methodology vary significantly from one index to another. There are three primary methodologies used to construct commodity indexes, that include production weighting, optimized weighting, and equal weighting. Production weighting involves assigning weights based on a moving average of world production. A production-weighted index will have a heavier weighting in sectors that may be 
more important in the economy, for example crude oil. These allocations will have a disproportionate impact on the performance of the index. An optimized-weighted index includes specific constraints and objectives such as correlation with inflation, negative correlation to equities and fixed income, a focus on liquidity, and the sectors that are most relevant. Finally, an equal-weighted index keeps price fluctuations in any one sector from disproportionately impacting the index, but does not over- or underweight sectors that may be more important in the economy (Busken 2004).

A dramatic increase in the number of indexes being published worldwide has come along with growing investors' interest in commodity investments. These indexes are widely used as price indicators for economists and investors. However, they are also rapidly assuming the role of comparison benchmarks in portfolio management, as well as acting as underlying instruments for certain derivative structures (Füss, Hoppe and Kaiser 2008). Currently, there are several large commodity indexes offered by different providers. The most important are: the Thomson Reuters/Core Commodity CRB Index (TR/CC CRB), the S\&P Goldman Sachs Commodity Index, the Bloomberg Commodity Index (former Dow-Jones AIG Commodity Index), and the Deutsche Bank Liquid Commodity Index. The present paper is aimed at assessing return and risk characteristics of these indexes and at providing a comparative analysis of their performance in comparison to the most important equity indexes, such as S\&P500, FTSE100, CAC40, DAX, WIG, BUX, IBovespa, Nikkei, Shanghai Composite (SSE), TSE300 (current S\&P/TSX Composite Index), and AOI (colloquially called All Ords). The paper is organized as follows. The next two sections present the data, methodology, and the results obtained. Finally, the last section provides a brief discussion and conclusions.

\section{Data and methodology}

Empirical data covers daily quotes of four commodity indexes and eleven equity indexes representing European, American, Asian and Australian stock markets from January 5, 2009 to December 30, 2015. The commodity indexes under consideration are the following:

- the Thomson Reuters/Core Commodity CRB Index,

- the S\&P Goldman Sachs Commodity Index,

- the Bloomberg Commodity Index (former Dow-Jones AIG Commodity Index),

- and the Deutsche BankLliquid Commodity Index.

The CRB Index is the oldest of the indexes. It was first calculated by the CRB in 1957 and made its inaugural in the 1958 CRB Commodity Year Book. The index, originally composed of 28 commodities, currently is made up of 19 commodities: aluminum, cocoa, coffee, copper, corn, cotton, crude oil, gold, heating oil, lean hogs, live cattle, natural gas, nickel, orange juice, silver, soybeans, sugar, unleaded gas, wheat. The 
tenth revision of the index renamed it the Tomson Reuters/Core Commodity CRB Index (TR/CC CRB). The index was originally designed to provide dynamic representation of broad trends in overall commodity prices, hence the periodic adjustments in order to reflect changes in market structure and activity.

The Goldman Sachs Commodity Index was created in 1991. It is a world-productionweighted index that is based on the average quantity of production of each commodity in the index, over last five years of available data. This allows the index to be a measure of investment performance as well as serve an economic indicator. It comprises 24 commodities from all commodity sectors (energy products, industrial metals, agricultural products, livestock products and precious metals). The wide range of constituent commodities provides the index with a high level of diversification across subsectors and within each subsector. In 2007, index ownership was transferred to Standard\&Poor's, who currently own and publish it as S\&P GSCI.

The Dow-Jones AIG Commodity Index, originally launched in 1998, was renamed to Dow Jones-USB Commodity Index, when UBS acquired it from AIG in 2009. On July 1, 2014 the index was rebranded under its current name - the Bloomberg Commodity Index (BCOM). It tracks prices of futures contracts on physical commodities on the commodity markets. The index is designed to minimize concentration in any one commodity or sector. It currently has 22 commodity futures in seven sectors. No one commodity can compose less than $2 \%$ or more than $15 \%$ of the index, and no sector can represent more than 33\% of the index. The weightings are calculated in accordance with rules that ensure that the relative proportion of each of the underlying individual commodities reflects its global economic significance and market liquidity.

The Deutsche Bank Liquid Commodity Index is composed of only 6 commodities all of each are among the most liquid in their sectors: sweet light crude oil (WTI), heating oil, aluminum, gold, wheat, and corn. These cover the biggest commodity sectors and are held in fixed notional amounts that reflect world production and inventories in these sectors. Notional weights refer to the US dollar weights of the various assets at the inception of the index in 1988. The index value is calculated daily using the closing prices of listed instruments on each of the commodities. The DBLCI has constant weightings for each of the 6 commodities (the index is rebalanced annually to reset weights back to fixed levels), however during the course of the year the weights fluctuate according to the price movement of the underlying commodity futures.

The stock indexes under consideration represent different stock markets. The representatives of European markets are:

BUX that is a blue chip stock market index consisting of the 25 major Hungarian companies trading on the Budapest Stock Exchange. It was launched in 1991. 
CAC 40, created in 1987, is a benchmark French stock market index. The index represents a capitalization-weighted measure of the 40 most significant values among the 100 highest market caps on the Euronext Paris (formerly the Paris Bourse). It is one of the main national indexes of the pan-European stock exchange group Euronext.

DAX (Deutscher Aktienindex) has been calculated since 1988. It is a blue chip stock market index consisting of the 30 major German companies trading on the Frankfurt Stock Exchange.

Financial Times Stock Exchange 100 Index (FTSE 100) founded in 1984 is a share index of the 100 companies listed on the London Stock Exchange with the highest market capitalization.

WIG, originally an acronym for Warszawski Indeks Giełdowy (Warsaw Stock Exchange Index) is the oldest index of the Warsaw Stock Exchange. It was introduced in April 1991. WIG lists 385 companies (as of December 18, 2015).

South and North American stock markets are represented by:

IBOVESPA which is the benchmark index of São Paulo Stock Exchange as it comprises the most representative companies in the market. It is the oldest BOVESPA index, being broadcast since 1968 .

Standard \& Poor's 500 (S\&P 500) is an American stock market index based on the market capitalizations of 500 large companies having common stock listed on the NYSE and NASDAQ. It is one of the most commonly followed equity indexes, and many consider it one of the best representations of the U.S. stock market. It has been calculated since March 1957.

TSE 300 Index was a Canadian stock market index that tracked the prices of 300 influential stocks which were traded on the Toronto Stock Exchange. Since May 1, 2002, it has been replaced by the S\&P/TSX Composite Index.

Asian stock markets indexes are:

Nikkei 225, more commonly called the Nikkei, is a stock market index for the Tokyo Stock Exchange. It has been calculated daily since 1950. Currently, the Nikkei is the most widely quoted average of Japanese equities.

Shanghai Composite Index (SSE) is a stock market index of all shares that are traded at the Shanghai Stock Exchange. It was established in 1991.

The last of the indexes under consideration is the All Ordinaries Index (AOI) representing Australian stock market. It was established in January 1980 and is the oldest equity index in Australia that is made up of the share prices for 500 of the largest companies listed on the Australian Securities Exchange. 
Figures 1 - 3 show the performance of commodity and stock indexes in the period from January 5, 2009 to December 30, 2015. In this period, the quotes of the Thomson Reuters/Core Commodity CRB Index ranged from the minimum of 170.7 (on December 17, 2015) to the maximum of 370.56 (on April 29, 2011). The DBLCI minimum (192.99) was observed on December 30, 2015, whereas its maximum (494.78) was recorded on April 29, 2011. Extreme levels of the Bloomberg Commodity Index were the following: minimum of 378.33 (observed on March 2, 2009) and maximum of 879.48 (on April 25,2011). The levels of the S\&P Goldman Sachs Commodity Index ranged between 305.01 on December 22, 2015 and 760.33 on April 8, 2001. Thus, three out of four commodity indexes reached their lows in December 2015 and all of them reached their highs in April 2011.

The European stock indexes exhibit the following extrema:

BUX: 9461.30 on March 12, 2009 and 25322.96 on April 6, 2010;

CAC40: 2519.29 (March 9, 2009) and 5268.91 (April 27, 2015);

DAX: 3666.41 (March 6,2009) and 12374.73 (April 10, 2015);

FTSE100: 3512.09 (March 3, 2009) and 7103.98 (April 27, 2015);

WIG: 21274.28 (February 17, 2009) and 57379.45 (May 8, 2015).

Thus, the majority of European indexes reached minimal levels in March 2009, whereas their maximal levels were observed in April 2015.

Other stock indexes exhibited similar performance. Their minima were recorded in March 2009 and their maxima in April 2015. The details are the following:

AOI: 3111.70 on March 6, 2009 and 5954.80 on April 27, 2015;

IBovespa: 36234.69 on March 2, 2009 and 72995.69 on November 4, 2010;

Nikkei: 7054.98 on March 10, 2009 and 20868.03 on June 24, 2015;

Shanghai Composite: 1863,37 on January 13, 2009 and 5166,35 on June 12, 2015,

S\&P500: 676.53 on March 9, 2009 and 2130.82 on May 21, 2015;

TSE300: 7566.94 on March 9, 2009 and 15657.63 on September 3, 2014.

In general, most of equity indexes reached their maxima in mid-2015, when commodity indexes exhibiting their counter-cyclic nature, fell down.

The first step to assess return and risk characteristics of the indexes is to estimate their logarithmic returns:

$r_{t}=p_{t}-p_{t-1}$, 
where $p_{t}$ is the logarithm of the index level at time $t$ and $p_{t-1}$ is the logarithm of the index level in the previous period.

Then, there are calculated descriptive characteristics.

1. Mean return is an indicator for the location of the return distribution. It is:

$$
\bar{r}=\frac{r_{1}+r_{2}+\ldots+r_{n}}{n} .
$$

2. Standard deviation:

$$
\sigma=\left(\frac{1}{n-1} \sum_{i=1}^{n}\left(r_{i}-\bar{r}\right)^{2}\right)^{0,5} .
$$

The standard deviation indicates the dispersion of the return distribution. It accounts for both the positive and negative deviations from the average value and is thus a measure for the total risk of an investment.

3. Semideviation:

$$
\sigma_{s}=\left(\frac{\sum_{i=1}^{n} d_{i}^{2}}{n-1}\right)^{0,5},
$$

where:

$$
d_{i}=\left\{\begin{array}{lll}
r_{i}-\bar{r} & \text { if } & r_{i}-\bar{r}<0 \\
0, & \text { if } & r_{i}-\bar{r} \geq 0
\end{array} .\right.
$$

The semideviation is a downside risk measure as it accounts only for negative deviations from the average, so it is believed to better reflect the real expectations of investors.

4. Skewness:

$$
S=\frac{\frac{1}{n} \sum_{i=1}^{n}\left(r_{i}-\bar{r}\right)^{3}}{\sigma^{3}} .
$$

The skewness describes the asymmetry of a probability distribution. If the distribution has a longer tail on the right (left) side then the distribution is referred to as positively (negatively) skewed. The skewness of a symmetrical probability distribution is equal to zero.

5. Kurtosis: 


$$
K=\frac{\frac{1}{n} \sum_{i=1}^{n}\left(r_{i}-\bar{r}\right)^{4}}{\sigma^{4}} .
$$

Kurtosis describes whether a probability distribution is more acute or wider in comparison to normal distribution, which has kurtosis of three. If the probability is more acute (wider) and has more (less) returns at tails than a normal distribution, then the distribution is referred to as leptocurtic (platycurtic). Having thick distribution ends ("fat tails") is referred to as having positive excess kurtosis; having thinner tails when compared to the normal distribution indicates negative excess kurtosis. According to Shore (2008) it would be ideal for an investment to have positive skewness coupled with high kurtosis so that it has a greater potential for positive extreme returns than negative extreme returns.

In order to assess linear dependence between commodity and equity indexes returns, Pearson correlation measure is considered. The Pearson correlation coefficient $k_{X Y}$ of indexes $\mathrm{X}$ and $\mathrm{Y}$ is:

$k_{X Y}=\frac{\sum_{i=1}^{n}\left(r_{X i}-\bar{r}_{X}\right)\left(r_{Y i}-\bar{r}_{Y}\right)}{(n-1) S_{X} S_{Y}}$.

Its value ranges between $\langle-1,1\rangle$. The higher the value of its modulus, the stronger the linear dependence between the investigated time-series.

For the purpose of analysis, there is also tested normality of distribution of time series under consideration. The normal distribution can be statistically verified using respective Jarque-Bera test.

The null hypothesis:

$\mathrm{H}_{0}$ : the returns follow a normal distribution

is tested against the alternative hypothesis

$\mathrm{H}_{1}$ : the returns do not follow a normal distribution.

The test statistic $J B$ is:

$$
J B=\frac{n}{6}\left[S^{2}+\frac{1}{4}(K-3)^{2}\right] .
$$

The statistic follows an asymptotic chi-squared distribution with two degrees of freedom. The hypothesis of normality is rejected at the $5 \%$ level if the JB test statistic is greater than 5.99 . 
The next step of the research uses the nonparametric Mann-Whitney test to verify whether the calculated commodity indexes returns differ significantly from equity indexes returns. The decision to use this nonparametric test is justified by the fact that returns of commodity indexes are generally not normally distributed (Füss, Hoppe and Kaiser 2008). This test, based on ranks, is the most useful in testing equality of means in two populations and is recommended when assumption of distribution normality is not fulfilled as the only assumption demanded is that all observations from both groups are independent to each other and were selected in the random way (Aczel 2000). First, one should arrange all observations into a single ranked series. If there are any equal values, they receive arithmetic averages of their ranks. Then one should add up the ranks for the observations coming from sample 1. The sum of ranks is denoted by $R_{1}$. The test statistic $U$ is given by:

$$
U=n_{1} n_{2}+\frac{n_{1}\left(n_{1}+1\right)}{2}-R_{1},
$$

where $n_{1}$ is the sample size for sample 1 , and $n_{2}$ is the sample size for sample 2 .

For large samples, when both $n_{1}$ and $n_{2}$ are larger than $10, U$ is approximately normally distributed. In that case, the standardized value $Z$ is given by:

$$
Z=\frac{U-\mu_{U}}{\sigma_{U}}
$$

where $\mu_{U}$ and $\sigma_{U}$ are the mean and standard deviation of $U$ given by:

$$
\mu_{U}=\frac{n_{1} n_{2}}{2},
$$

and

$$
\sigma_{U}=\sqrt{\frac{n_{1} n_{2}\left(n_{1}+n_{2}+1\right)}{12}} .
$$

It is worth noticing these calculations are not based on values of separate characteristics. They are based on sample sizes (Mynarski 2006).

\section{Results}

On the base of 1804 observations for each of the considered indexes, there were calculated their logarithmic returns that are used to evaluate descriptive statistics given in table 1. These are: minimal and maximal observed values, expected rate of return (mean), standard deviation, semideviation, skewness, kurtosis and JarqueBera statistics. Almost all commodity indexes are characterized by negative mean returns. The only exception is Bloomberg Commodity Index (BCOM). Its mean return is greater than this of IBovespa which is the stock index that produced the lowest 
positive return. The highest positive expected rate of return is that of S\&P500. In general, equity indexes exhibit positive mean returns. Taken into account both standard an semideviation, the Shanghai Composite (SSE) is the riskiest one among investigated indexes, whereas the least risky is the AOI. All commodity and equity indexes are described by negative skewness, so there is a higher probability of high negative daily returns when compared to the normal distribution. Moreover, kurtosis is higher than 3 for six out of eleven equity indexes whose distributions are leptokurtic, then. These indexes are: BUX, Nikkei, Shanghai Composite, S\&P 500, TSE300, and WIG. Negative skewness and positive excess kurtosis are distribution properties, which investors do not appreciate, because they imply more overall large returns (positive and negative) compared to the normal distribution. The larger negative returns are generally not compensated for by larger positive returns. Distributions of other equity indexes and all commodity indexes are platycurtic. The risk-averse investors prefer negative excess kurtosis or in comparison to normal distribution lower probability of extreme values. The Jarque-Bera test statistc (JB) of normality confirms the rejection of null hypothesis at $5 \%$ level of significance for all commodity and stock indexes.

To investigate linear dependencies between commodity and equity indexes returns, Pearson correlation coefficients are calculated. Their values are reported in table 2 . In general, all indexes are characterized by positive linear correlation (the weakest dependencies are between the commodity indexes and the AOI, the strongest between commodity indexes and the TSE300).

In order to assess profitability of commodity investments in relation to stock investments, the Mann-Whitney test was used to verify the hypothesis:

$\mathrm{H}_{0}$ : mean values of logarithmic returns series of $\mathrm{X}$ index and $\mathrm{Y}$ index are equal against

$\mathrm{H}_{1}$ : mean values of logarithmic returns series of $\mathrm{X}$ index and $\mathrm{Y}$ index differ significantly.

At the significance level 0.05 , critical value of standardized normal distribution equals $\pm 1,96$, so critical areas for hypothesis formulated above are the following: $(-\infty,-1,96)$ and $(1,96,+\infty)$. Results of verification ( $\mathrm{Z}$ statistics), presented in table 3 , let us generally conclude that in the considered period mean returns on separate commodity and equity indexes did not differ significantly as in most cases the null hypothesis cannot be rejected. However, there are some exceptions. These are: DAX with TR/CC CRB and with DBLCI, Nikkei with TR/CC CRB and with DBLCI, Shanghai Composite with TR/CC CRB and with DBLCI, S\&P500 with TR/CC CRB and BCOM, and TSE300 with TR/CC CRB and with DBLCI. Thus the TR/CC CRB and the DBLCI were the only commodity indexes whose mean returns were significantly different from mean returns of equity indexes. 
Apart from the expected rate of return (mean), another basic characteristic of every investment is its level of risk. In the case of commodity investments, it is often believed that their returns are less volatile and thus less risky. In order to verify the hypothesis with regard to indirect commodity investments through commodity indexes, there were calculated absolute values of returns deviations from the mean. Then, the Whitney-Mann test was applied again, but this time observations were ordered in the descendent way (higher absolute deviations received lower rank numbers).

The following hypothesis was verified:

$\mathrm{H}_{0}$ : deviations of $\mathrm{X}$ index rates of return from the mean are identical as deviations of $\mathrm{Y}$ index rates of return

against

$\mathrm{H}_{1}$ : deviations of $\mathrm{X}$ index rates of return from the mean differ significantly from deviations of $Y$ index rates of return.

Results of testing (Z statistics) are reported in table 4. In most cases they indicate rejection of the null hypothesis implying that deviations of separate commodity indexes rates of return from their means differed significantly from the deviations of equity indexes rates of return from their means. More detailed analysis leads to the conclusion that in some cases deviations from means exhibited by stock indexes were higher than those of their commodity counterparties (as for IBovespa, BUX, CAC40, Nikkei, Shanghai Composite.) In other cases they exhibited lower deviations from their means (as for AOI, FSE100, S\&P500, TSE300, WIG). The evidence for DAX is not clear as it exhibits lower deviations when compared to TR/CC CRB and higher when compared to BCOM. Thus it is legitimate to conclude that indirect investing in commodities through commodity indexes may be attractive to risk-averse investors due to the lower risk in comparison to investments on Brazilian, Hungarian, French, Japanese and Chinese stock markets. On the contrary, investments on Australian, British, North American and Polish stock markets appear to be less risky in comparison to investments through commodity indexes. Nevertheless, one should be cautious about the conclusions formulated on the base of Mann-Whitney test as commodity and stock indexes returns reveal positive correlation. Thus empirical data used for the purpose of testing may differ from the typical pattern for two simple independent samples extracted from two different populations. 


\section{Concluding remarks}

In recent years, alternative investments have gained widespread acceptance due to their attractive risk-return characteristics and their low correlations to traditional asset classes, such as stocks and bonds. This paper is focused on commodity indexes and investigates the performance of selected commodity and stock indexes over the 2009 to 2015 period. These indexes are: the Thomson Reuters/Core Commodity CRB Index, the S\&P Goldman Sachs Commodity Index, the Bloomberg Commodity Index (former Dow-Jones AIG Commodity Index), the Deutsche Bank Liquid Commodity Index, S\&P500, FTSE100, CAC40, DAX, WIG, BUX, IBovespa, Nikkei, Shanghai Composite (SSE), TSE300 (current S\&P/TSX Composite Index), and AOI (All Ords). On the base of their logarithmic returns there were calculated descriptive characteristics, such as mean return, standard deviation and semideviation, kurtosis, skewness and correlation. Then the normality of distribution of investigated time-series was tested. In all cases one should reject the hypothesis of distribution normality. Thus in the next step of the research the Mann-Whitney test was used to verify the hypotheses of equality of means and deviations from mean of logarithmic returns of analyzed indexes.

The research revealed that in the considered period majority of stock indexes generated returns no different from the commodity indexes. In some cases stock indexes returns were more volatile and in some other less volatile in comparison to commodity indexes. Nevertheless, one could draw the general conclusion that investments through commodity indexes did not seem much more attractive in comparison to the stock markets. It corresponds with Gilbert's opinion that commodity investments are generally justified more in terms of their contribution to overall portfolio returns than as attractive stand alone investment (Gilbert 2008). Author's earlier research (Krawiec 2011) investigating indirect commodity investments through commodity-based equities listed on the Warsaw Stock Exchange from December 2008 through March 2011 and commodity mutual funds led to the similar conclusion. However it is worth to remember that the current study presented here covers a specific period as in 2015 most commodities fell significantly and commodity indexes suffered losses as well. That is why commodity investments were hit hard and resulting from that equities outperformed commodities. It was Faber who in 2004 cautioned that commodity markets could reach all time highs and subsequently new lows within a brief period of time, and that investors should have been prepared to occasional $50 \%$ declines in the prices of commodities (Faber 2004). Moreover, Jodie Gunzberg, global head of commodities at S\&P Dow Jones Indices, interviewed by Rajesh Bhayani in March 2016, observed that 2015 would go down in history as one of the worst years ever for commodities. Nevertheless, she expected 2016 to bring good news for the market (www.businesss-standard.com). 


\section{References}

[1] Ackworth, W. (2005). Going Long on Commodities. Futures Industry Magazine, May-June. https://fimag.fia.org.

[2] Aczel, A. D. (2000). Statistics in Management, Warsaw: WN PWN (in Polish).

[3] Akey, R.P. (2005). Commodities: A Case for Active Management, www.dnb.co.in

[4] Anson, M.J.P. (2008). The Pricing and Economics of Commodity Futures. The Handbook of Commodity Investing, Chichester, West Sussex: John Wiley\&Sons, 38-55.

[5] Bessler, W., Wolff, D. (2015). Do Commodities Add Value in Multi-asset Portfolios? An Out-of-sample Analysis for Different Investment Strategies. Journal of Banking and Finance, 60, 1-20.

[6] Bodie Z., Rozansky V. (1980). Risk and Return in Commodity Futures. Financial Analyst Journal, 36, 27-39.

[7] Busken, Ch. (2004). Investing in Commodities. Fund Evaluation Group, Fall, www.feg.com.

[8] Chevalier, J., Ielpo, F. (2013). The Economic of Commodity Markets. Chichester, West Sussex: John Wiley\&Sons.

[9] Engelke, L., Yuen J.C. (2008). Types of Commodity Investments. The Handbook of Commodity Investing. Chichester, West Sussex: John Wiley\&Sons, 549-569.

[10] Faber, M. (2004). Booming Commodity Prices, but ..., www.safehaven.com.

[11] Fabozzi, J., Füss, R., Kaiser D.G. (2008). A Primer on Commodity Investing. The Handbook of Commodity Investing. Chichester, West Sussex: John Wiley\&Sons, 3-37.

[12] Füss, R., Hoppe Ch., Kaiser, D.G. (2008). Review of Commodity Futures Performance Benchmarks. The Handbook of Commodity Investing. Chichester, West Sussex: John Wiley\&Sons, 169-202.

[13] Geman, H. (2007). Commodities and Commodity Derivatives, Chichester, West Susex: John Wiley\&Sons.

[14] Gilbert, Ch.L., (2008). Commodity Speculation and Commodity Investment. Discussion Paper No. 20, Universita degli Studi di Trento, Dipartimento di Economia, www.unitn.it

[15] Gorton, G., Rouwenhorst, K.G. (2004). Facts and Fantasies About Commodity Futures. Financial Analyst Journal, 62, 47-68. 
[16] Greer, R.J. (2000). The Nature of Commodity Index Returns. Journal of Alternative Investments, 3 (1), 2000, 45-52.

[17] Kat, H.M., Oomen, R.C.A. (2007). What Every Investor Should Know About Commodities, Part I, Univariate Return Analysis. Journal of Investment Management 5 (1), 1-25.

[18] Koutsoftas, N., Ross, B., Fila, G. (2010). Commodities and the Efficient Frontier. Canadian Investment Review, www.investmentreview.com.

[19] Krawiec, M. (2011). Efficiency of Indirect Ways of Investing in Commodities in Conditions of Polish Capital Market. Quantitative Methods in Economics, 12 (1), 105-117.

[20] Mynarski, S. (2006). Analysis of Market Data with the Use of Excel. Cracow: Cracow Economic University Press (in Polish).

[21] Proelss, J., Schweizer, D. (2008). Efficient Frontier of Commodity Portfolios. The Handbook of Commodity Investing. Chichester, West Sussex: John Wiley\&Sons, 454-478.

[22] Rouwenhorst, K.G. (2012). Commodity Investing. Annual Review of Financial Economics, 4, 447-467.

[23] Schofield, N.C. (2007). Commodity Derivatives. Chichester, West Sussex: John Wiley\&Sons.

[24] Shore, M.S. (2008). Introducing Alternative Investments in a Traditional Portfolio: the Case of Commodities, Hedge Funds, and Managed Futures. The Handbook of Commodity Investing. Chichester, West Sussex: John Wiley\&Sons, 504-521.

[25] You, L., Daigler, R.T. (2012). A Markowitz Optimization of Commodity Futures. Journal of Futures Markets, 33 (4), 343-368.

Table 1. Descriptive statistics for commodity and stock indexes

\begin{tabular}{|c|c|c|c|c|c|c|c|c|}
\hline \multirow{2}{*}{ Index } & \multicolumn{9}{|c|}{ Min } & Max & Mean & $\begin{array}{c}\text { Std. } \\
\text { dev. }\end{array}$ & $\begin{array}{c}\text { Semidev } \\
\text {. }\end{array}$ & $\begin{array}{c}\text { Skewnes } \\
\text { s }\end{array}$ & $\begin{array}{c}\text { Kurtosi } \\
\text { s }\end{array}$ & JB \\
\hline AOI & - & 0.0343 & 0.0002 & 0.0096 & 0.00699 & -0.29180 & 1.4501 & $183.559^{*}$ \\
& 0.0430 & 7 & 1 & 0 & & & & \\
\hline $\begin{array}{c}\text { IBovesp } \\
\text { a }\end{array}$ & - & 0.0574 & 0.0000 & 0.0146 & 0.01032 & -0.04387 & 1.5850 & $189.310^{*}$ \\
& 0 & 6 & 2 & 0 & & & & \\
\hline
\end{tabular}




\begin{tabular}{|c|c|c|c|c|c|c|c|c|}
\hline BUX & $\begin{array}{c}- \\
0.0757 \\
0\end{array}$ & $\begin{array}{c}0.1060 \\
7\end{array}$ & $\begin{array}{c}0.0003 \\
5\end{array}$ & $\begin{array}{c}0.0148 \\
5\end{array}$ & 0.01040 & 0.12885 & 3.3226 & $834.333^{*}$ \\
\hline CAC40 & $\begin{array}{c}- \\
0.0563 \\
5\end{array}$ & $\begin{array}{c}0.0922 \\
1\end{array}$ & $\begin{array}{c}0.0001 \\
8\end{array}$ & $\begin{array}{c}0.0140 \\
2\end{array}$ & 0.01005 & -0.02421 & 2.6703 & $535.842^{*}$ \\
\hline DAX & $\begin{array}{c}- \\
0.0599 \\
5\end{array}$ & $\begin{array}{c}0.0589 \\
5\end{array}$ & $\begin{array}{c}0.0004 \\
3\end{array}$ & $\begin{array}{c}0.0136 \\
5\end{array}$ & 0.00986 & -0.16146 & 2.0316 & $317.904^{*}$ \\
\hline $\begin{array}{c}\text { FTSE10 } \\
0\end{array}$ & $\begin{array}{c}- \\
0.0548 \\
0\end{array}$ & $\begin{array}{c}0.0503 \\
2\end{array}$ & $\begin{array}{c}0.0001 \\
8\end{array}$ & $\begin{array}{c}0.0106 \\
2\end{array}$ & 0.00769 & -0.19895 & 2.6860 & $553.910^{*}$ \\
\hline Nikkei & $\begin{array}{c}- \\
0.1115 \\
0\end{array}$ & $\begin{array}{c}0.0742 \\
6\end{array}$ & $\begin{array}{c}0.0004 \\
1\end{array}$ & $\begin{array}{c}0.0137 \\
4\end{array}$ & 0.01011 & -0.52206 & 4.3665 & $\begin{array}{c}1514.240 \\
*\end{array}$ \\
\hline SSE & $\begin{array}{c}- \\
0.0887 \\
3\end{array}$ & $\begin{array}{c}0.0636 \\
9\end{array}$ & $\begin{array}{c}0.0003 \\
5\end{array}$ & $\begin{array}{c}0.0151 \\
0\end{array}$ & 0.01127 & -0.70799 & 4.7441 & $\begin{array}{c}1841.440 \\
*\end{array}$ \\
\hline S\&P500 & $\begin{array}{c}- \\
0.0689 \\
6\end{array}$ & $\begin{array}{c}0.0683 \\
7\end{array}$ & $\begin{array}{c}0.0004 \\
4\end{array}$ & $\begin{array}{c}0.0110 \\
6\end{array}$ & 0.00806 & -0.21429 & 4.4919 & $\begin{array}{c}1529.580 \\
*\end{array}$ \\
\hline TSE300 & $\begin{array}{c}- \\
0.0551 \\
1\end{array}$ & $\begin{array}{c}0.0517 \\
9\end{array}$ & $\begin{array}{c}0.0001 \\
9\end{array}$ & $\begin{array}{c}0.0096 \\
7\end{array}$ & 0.00716 & -0.39523 & 3.1035 & $770.539 *$ \\
\hline WIG & $\begin{array}{c}- \\
0.0688 \\
1 \\
\end{array}$ & $\begin{array}{c}0.0579 \\
9\end{array}$ & $\begin{array}{c}0.0002 \\
7\end{array}$ & $\begin{array}{c}0.0114 \\
6\end{array}$ & 0.00835 & -0.37869 & 4.2512 & $\begin{array}{c}1400.800 \\
*\end{array}$ \\
\hline $\begin{array}{c}\mathrm{TR} / \mathrm{CC} \\
\mathrm{CRB}\end{array}$ & $\begin{array}{c}- \\
0.0569 \\
7\end{array}$ & $\begin{array}{c}0.0578 \\
5\end{array}$ & $\begin{array}{c}- \\
0.0002 \\
0\end{array}$ & $\begin{array}{c}0.0105 \\
8\end{array}$ & 0.00766 & -0.24681 & 2.9802 & $686.526^{*}$ \\
\hline DBLCI & $\begin{array}{c}- \\
0.0602 \\
1\end{array}$ & $\begin{array}{c}0.0561 \\
0\end{array}$ & $\begin{array}{c}- \\
0.0003 \\
4\end{array}$ & $\begin{array}{c}0.0123 \\
2\end{array}$ & 0.00884 & -0.14115 & 2.0049 & $307.943^{*}$ \\
\hline BCOM & $\begin{array}{c}- \\
0.0491 \\
2\end{array}$ & $\begin{array}{c}0.0524 \\
3\end{array}$ & $\begin{array}{c}0.0000 \\
3\end{array}$ & $\begin{array}{c}0.0102 \\
3\end{array}$ & 0.00734 & -0.14875 & 2.1743 & $361.817^{*}$ \\
\hline $\begin{array}{l}\text { S\&P } \\
\text { GSCI }\end{array}$ & $\begin{array}{c}- \\
0.0708 \\
8 \\
\end{array}$ & $\begin{array}{c}0.0595 \\
9\end{array}$ & $\begin{array}{c}- \\
0.0001 \\
0\end{array}$ & $\begin{array}{c}0.0133 \\
1\end{array}$ & 0.00959 & -0.18288 & 2.6860 & $552.050^{*}$ \\
\hline
\end{tabular}

Source: own calculations

Note: * Indicates rejection of the null hypothesis at $5 \%$. 
Table. 2. Coefficients of correlation between selected commodity and stock indexes

\begin{tabular}{|c|c|c|c|c|}
\hline Index & TR/CC CRB & DBLCI & BCOM & S\&P GSCI \\
\hline AOI & 0.190 & 0.149 & 0.194 & 0.172 \\
\hline IBovespa & 0.446 & 0.421 & 0.441 & 0.436 \\
\hline BUX & 0.322 & 0.298 & 0.355 & 0.326 \\
\hline CAC40 & 0.441 & 0.407 & 0.473 & 0,434 \\
\hline DAX & 0.427 & 0.393 & 0.459 & 0.419 \\
\hline FTSE100 & 0.467 & 0.443 & 0.505 & 0.470 \\
\hline Nikkei & 0.146 & 0.094 & 0.126 & 0.112 \\
\hline SSE & 0.183 & 0.151 & 0.203 & 0.150 \\
\hline S\&P500 & 0.474 & 0.466 & 0.475 & 0.485 \\
\hline TSE300 & 0.556 & 0.550 & 0.567 & 0.564 \\
\hline WIG & 0.400 & 0.374 & 0.437 & 0.393 \\
\hline
\end{tabular}

Source: own calculations

Table 3. Man-Whitney test results fo commodity and stock indexes mean returns

\begin{tabular}{|c|c|c|c|c|c|c|c|}
\hline Pair & $\mathrm{Z}$ & Pair & $\mathrm{Z}$ & & $\mathrm{Z}$ & Pair & $\mathrm{Z}$ \\
\hline $\begin{array}{c}\text { AOI-TR/CC } \\
\text { CRB }\end{array}$ & $\begin{array}{c}- \\
1.447 \\
\end{array}$ & $\begin{array}{c}\text { BUX-S\&P } \\
\text { GSCI }\end{array}$ & -0.623 & $\begin{array}{c}\text { FTSE100- } \\
\text { BCOM }\end{array}$ & -0.850 & $\begin{array}{c}\text { S\&P500- } \\
\text { DBLCI }\end{array}$ & \begin{tabular}{|c|}
- \\
$2.618^{*}$
\end{tabular} \\
\hline AOI-DBLCI & $\begin{array}{c}- \\
1.748\end{array}$ & $\begin{array}{c}\text { CAC40- } \\
\text { TR/CC CRB }\end{array}$ & -1.366 & $\begin{array}{l}\text { FTSE100- } \\
\text { S\&P GSCI }\end{array}$ & -0.793 & $\begin{array}{c}\text { S\&P500- } \\
\text { BCOM }\end{array}$ & $\begin{array}{c}- \\
2.028^{*} \\
\end{array}$ \\
\hline AOI- BCOM & $\begin{array}{c}- \\
0.905 \\
\end{array}$ & $\begin{array}{c}\text { CAC40- } \\
\text { DBLCI }\end{array}$ & -1.625 & $\begin{array}{c}\text { Nikkei- } \\
\text { TR/CC CRB }\end{array}$ & $\begin{array}{c}- \\
2.197^{*}\end{array}$ & $\begin{array}{l}\text { S\&P500- } \\
\text { S\&P GSCI }\end{array}$ & -1.744 \\
\hline $\begin{array}{c}\text { AOI-S\&P } \\
\text { GSCI }\end{array}$ & $\begin{array}{c}- \\
0.878 \\
\end{array}$ & $\begin{array}{c}\text { CAC40- } \\
\text { BCOM }\end{array}$ & -0.901 & $\begin{array}{l}\text { Nikkei- } \\
\text { DBLCI }\end{array}$ & $\begin{array}{c}- \\
2.391 *\end{array}$ & $\begin{array}{c}\text { TSE300- } \\
\text { TR/CC CRB }\end{array}$ & -1.823 \\
\hline $\begin{array}{l}\text { IBovespa- } \\
\text { TR/CC CRB }\end{array}$ & $\begin{array}{c}- \\
0.154 \\
\end{array}$ & $\begin{array}{c}\text { CAC40-S\&P } \\
\text { GSCI }\end{array}$ & -0.870 & $\begin{array}{c}\text { Nikkei- } \\
\text { BCOM }\end{array}$ & -1.723 & $\begin{array}{c}\text { TSE300- } \\
\text { DBLCI }\end{array}$ & $\begin{array}{c}- \\
2.021^{*}\end{array}$ \\
\hline $\begin{array}{l}\text { IBovespa- } \\
\text { DBLCI }\end{array}$ & $\begin{array}{c}- \\
0.547\end{array}$ & $\begin{array}{c}\text { DAX-TR/CC } \\
\text { CRB }\end{array}$ & $\begin{array}{c}- \\
2.159 *\end{array}$ & $\begin{array}{c}\text { Nikkei-S\&P } \\
\text { GSCI }\end{array}$ & -1.651 & $\begin{array}{c}\text { TSE300- } \\
\text { BCOM }\end{array}$ & -1.319 \\
\hline $\begin{array}{l}\text { IBovespa- } \\
\text { BCOM }\end{array}$ & $\begin{array}{c}- \\
0.330 \\
\end{array}$ & DAX-DBLCI & $\begin{array}{c}- \\
2.333^{*}\end{array}$ & $\begin{array}{c}\text { SSE-TR/CC } \\
\text { CRB }\end{array}$ & $\begin{array}{c}- \\
2.039 *\end{array}$ & $\begin{array}{l}\text { TSE300- } \\
\text { S\&P GSCI }\end{array}$ & -1.119 \\
\hline $\begin{array}{l}\text { IBovespa- } \\
\text { S\&P GSCI }\end{array}$ & $\begin{array}{c}- \\
0.123\end{array}$ & DAX-BCOM & -1.694 & SSE-DBLCI & ${ }^{-}$ & $\begin{array}{c}\text { WIG-TR/CC } \\
\text { CRB }\end{array}$ & -1.595 \\
\hline $\begin{array}{c}\text { BUX-TR/CC } \\
\text { CRB }\end{array}$ & $\begin{array}{c}- \\
0.996 \\
\end{array}$ & $\begin{array}{c}\text { DAX-S\&P } \\
\text { GSCI }\end{array}$ & -1.561 & SSE-BCOM & -1.612 & WIG-DBLCI & -1.878 \\
\hline BUX-DBLCI & $\begin{array}{c}- \\
1.312 \\
\end{array}$ & $\begin{array}{c}\text { FTSE100- } \\
\text { TR/CC CRB }\end{array}$ & -1.348 & $\begin{array}{c}\text { SSE-S\&P } \\
\text { GSCI }\end{array}$ & -1.518 & WIG-BCOM & -1.091 \\
\hline BUX-BCOM & $\begin{array}{c}- \\
0.506 \\
\end{array}$ & $\begin{array}{l}\text { FTSE100- } \\
\text { DBLCI }\end{array}$ & -1.646 & $\begin{array}{c}\text { S\&P500- } \\
\text { TR/CC CRB }\end{array}$ & $\begin{array}{c}- \\
2.482^{*} \\
\end{array}$ & $\begin{array}{c}\text { WIG-S\&P } \\
\text { GSCI }\end{array}$ & -1.043 \\
\hline
\end{tabular}


Table 4 Man-Whitney test results for deviations from mean return on commodity and stock indexes

\begin{tabular}{|c|c|c|c|c|c|c|c|}
\hline Pair & $\mathrm{Z}$ & Pair & $\mathrm{Z}$ & Pair & $\mathrm{Z}$ & Pair & $\mathrm{Z}$ \\
\hline $\begin{array}{c}\text { AOI-TR/CC } \\
\text { CRB }\end{array}$ & -1.518 & $\begin{array}{c}\text { BUX-S\&P } \\
\text { GSCI }\end{array}$ & $-3.012^{*}$ & $\begin{array}{l}\text { FTSE100- } \\
\text { BCOM }\end{array}$ & -0.090 & $\begin{array}{l}\text { S\&P500- } \\
\text { DBLCI }\end{array}$ & $-7.425^{*}$ \\
\hline AOI-DBLCI & $\begin{array}{c}- \\
6.721^{*}\end{array}$ & $\begin{array}{c}\text { CAC40- } \\
\text { TR/CC CRB }\end{array}$ & $-7.645^{*}$ & $\begin{array}{l}\text { FTSE100- } \\
\text { S\&P GSCI }\end{array}$ & $\begin{array}{c}- \\
6.591^{*}\end{array}$ & $\begin{array}{l}\text { S\&P500- } \\
\text { BCOM }\end{array}$ & $-2.168^{*}$ \\
\hline AOI- BCOM & -1.169 & $\begin{array}{l}\text { CAC40- } \\
\text { DBLCI }\end{array}$ & $-2.619^{*}$ & $\begin{array}{c}\text { Nikkei- } \\
\text { TR/CC CRB }\end{array}$ & $\begin{array}{c}- \\
8.038^{*} \\
\end{array}$ & $\begin{array}{l}\text { S\&P500- } \\
\text { S\&P GSCI }\end{array}$ & $-8.404^{*}$ \\
\hline $\begin{array}{c}\text { AOI-S\&P } \\
\text { GSCI }\end{array}$ & $\begin{array}{c}- \\
7.734^{*} \\
\end{array}$ & $\begin{array}{l}\text { CAC40- } \\
\text { BCOM }\end{array}$ & $-8.024^{*}$ & $\begin{array}{l}\text { Nikkei- } \\
\text { DBLCI }\end{array}$ & $\begin{array}{c}- \\
2.989 * \\
\end{array}$ & $\begin{array}{c}\text { TSE300- } \\
\text { TR/CC CRB }\end{array}$ & $4.171^{*}$ \\
\hline $\begin{array}{l}\text { IBovespa- } \\
\text { TR/CC CRB }\end{array}$ & $\begin{array}{c}- \\
9.091^{*}\end{array}$ & $\begin{array}{c}\text { CAC40-S\&P } \\
\text { GSCI }\end{array}$ & -1 & $\begin{array}{l}\text { Nikkei- } \\
\text { BCOM }\end{array}$ & $\begin{array}{c}- \\
8.429 * \\
\end{array}$ & $\begin{array}{c}\text { TSE300- } \\
\text { DBLCI }\end{array}$ & $9.228 *$ \\
\hline $\begin{array}{l}\text { IBovespa- } \\
\text { DBLC }\end{array}$ & $\begin{array}{c}- \\
4.109 * \\
\end{array}$ & $\begin{array}{c}\text { DAX-TR/CC } \\
\text { CRB } \\
\end{array}$ & $50.114^{*}$ & $\begin{array}{c}\text { Nikkei-S\&P } \\
\text { GSCI }\end{array}$ & -1.834 & $\begin{array}{c}\text { TSE300- } \\
\text { BCOM }\end{array}$ & $3.846^{*}$ \\
\hline $\begin{array}{c}\text { IBovespa- } \\
\text { BCOM }\end{array}$ & $\begin{array}{c}- \\
9.521^{*}\end{array}$ & DAX-DBLCI & -1.219 & $\begin{array}{c}\text { SSE-TR/CC } \\
\text { CRB }\end{array}$ & $\begin{array}{c}- \\
5.356^{*}\end{array}$ & $\begin{array}{l}\text { TSE300- } \\
\text { S\&P GSCI }\end{array}$ & $\begin{array}{c}- \\
10.156^{*}\end{array}$ \\
\hline $\begin{array}{l}\text { IBovespa- } \\
\text { S\&P GSCI }\end{array}$ & $\begin{array}{c}- \\
3.012^{*}\end{array}$ & DAX-BCOM & $-6.560 *$ & SSE-DBLCI & -0.562 & $\begin{array}{c}\text { WIG-TR/CC } \\
\text { CRB }\end{array}$ & -0.330 \\
\hline $\begin{array}{c}\text { BUX-TR/CC } \\
\text { CRB }\end{array}$ & $\begin{array}{c}- \\
9.091^{*}\end{array}$ & $\begin{array}{c}\text { DAX-S\&P } \\
\text { GSCI }\end{array}$ & -0.113 & SSE-BCOM & $\begin{array}{c}- \\
5.644^{*}\end{array}$ & WIG-DBLCI & $-4.812^{*}$ \\
\hline BUX-DBLCI & $\begin{array}{c}- \\
4.109 *\end{array}$ & $\begin{array}{l}\text { FTSE100- } \\
\text { TR/CC CRB }\end{array}$ & -0.463 & $\begin{array}{c}\text { SSE-S\&P } \\
\text { GSCI }\end{array}$ & 0.524 & WIG-BCOM & -0.727 \\
\hline BUX-BCOM & $\begin{array}{c}- \\
9.521^{*}\end{array}$ & $\begin{array}{l}\text { FTSE100- } \\
\text { DBLCI }\end{array}$ & $-5.625^{*}$ & $\begin{array}{c}\text { S\&P500- } \\
\text { TR/CC CRB }\end{array}$ & $\begin{array}{c}- \\
2.485^{*}\end{array}$ & $\begin{array}{c}\text { WIG-S\&P } \\
\text { GSCI }\end{array}$ & $-5.790 *$ \\
\hline
\end{tabular}

Source: own calculations $\quad$ Note: ${ }^{*}$ Indicates rejection of the null hypothesis at $5 \%$. 
Figure 1. Commodity indexes from January 5, 2009 to December 30, 2015: the Reuters/ Core Commodity CRB Index (a), Bloomberg Commodity Index (b), S\&P Goldman Sachs Commodity Index (c), Deutsche Bank Liquid Commodity Index (d).

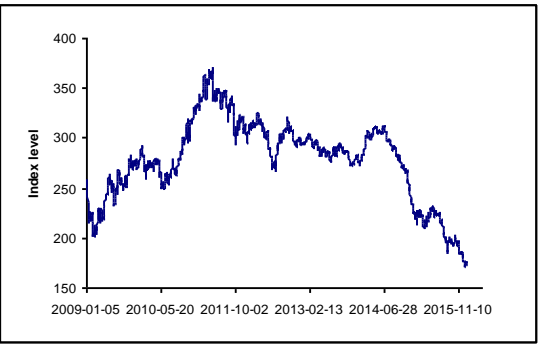

(a)

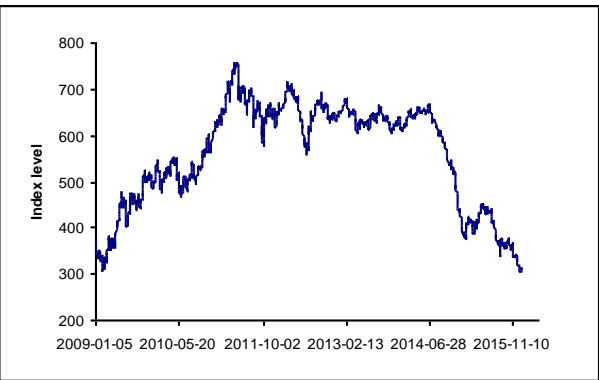

(c)

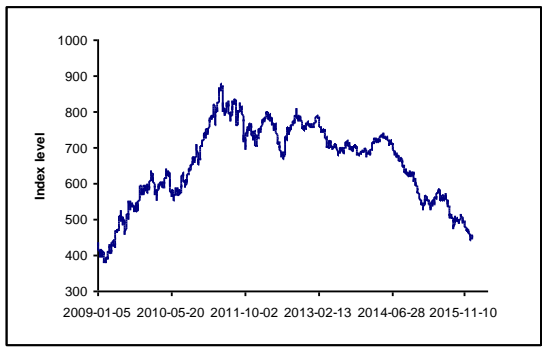

(b)

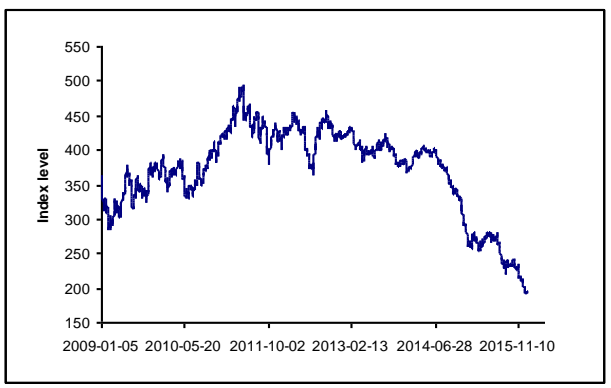

(d)

Source: Own elaboration 
Figure 2. European stock indexes from January 5, 2009 to December 30, 2015: BUX (a), CAC40 (b), DAX (c), FTSE100 (d), WIG (e)

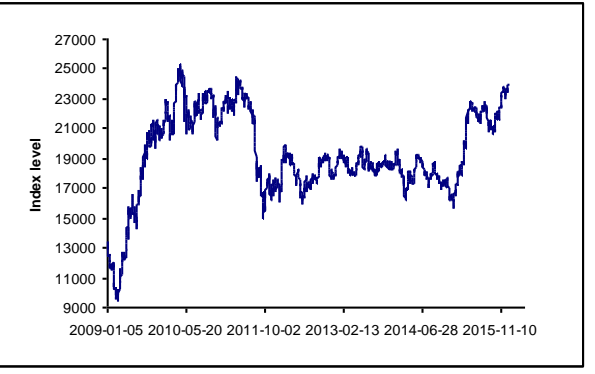

(a)

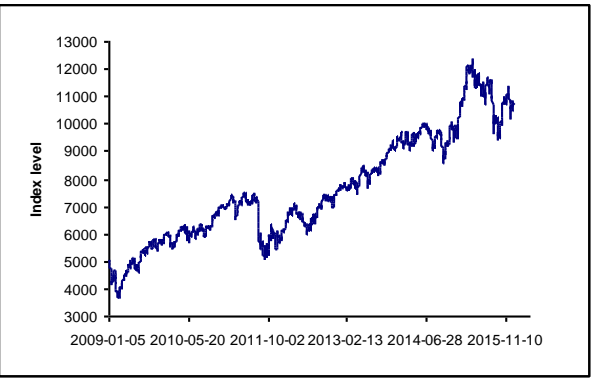

(c)

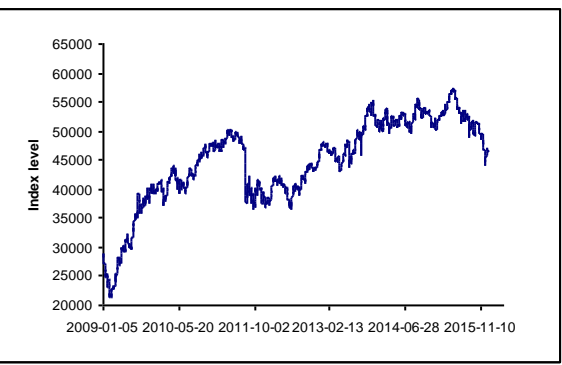

(e)

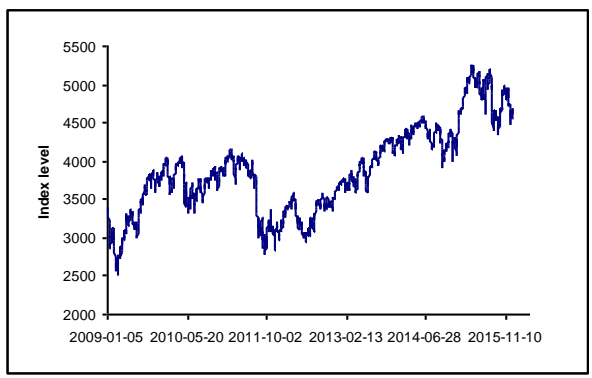

(b)

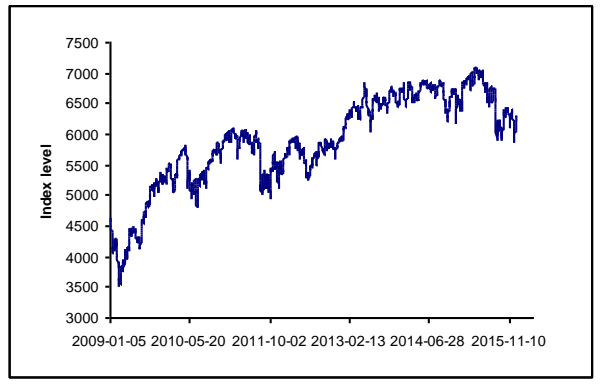

(d)

Source: Own elaboration 
Figure 3. Australian, Asian and American stock indexes from January 5, 2009 to December 30, 2015: AOI (a), Nikkei (b), SSE (c), IBovespa (d), S\&P500 (e), TSE300 (f)

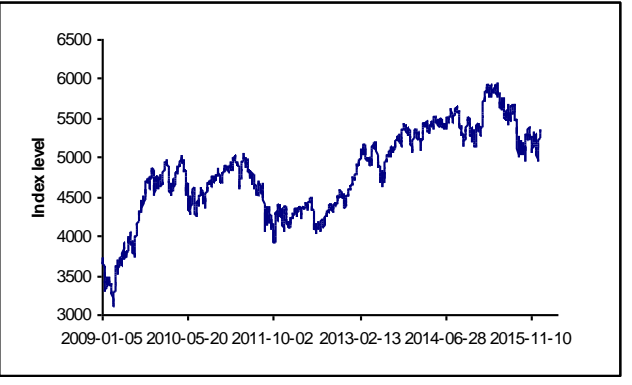

(a)

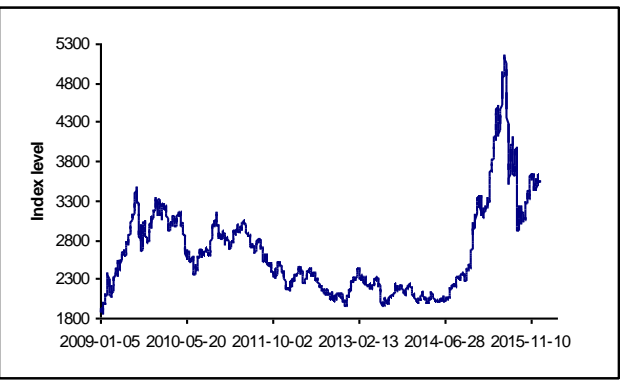

(c)

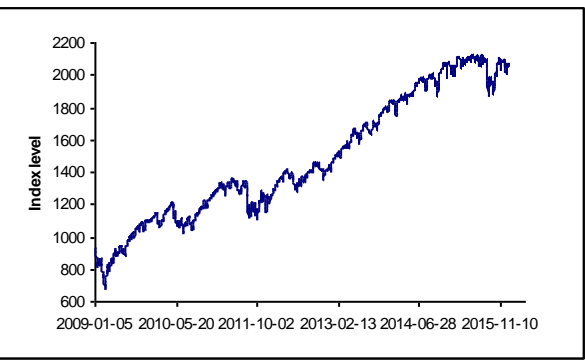

(e)

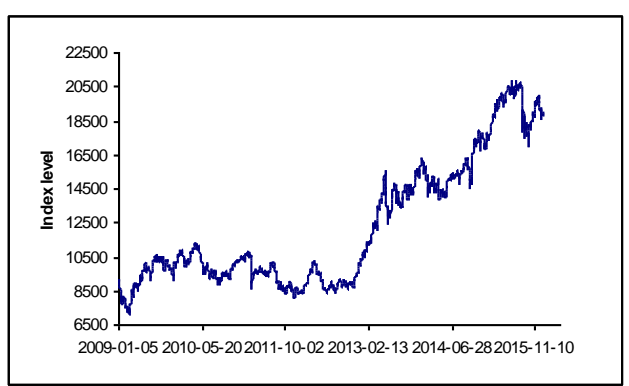

(b)

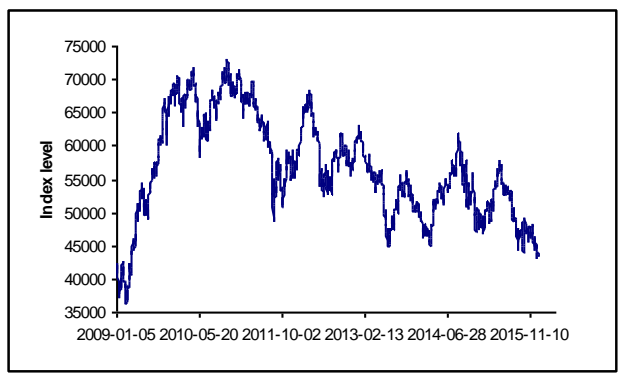

(d)

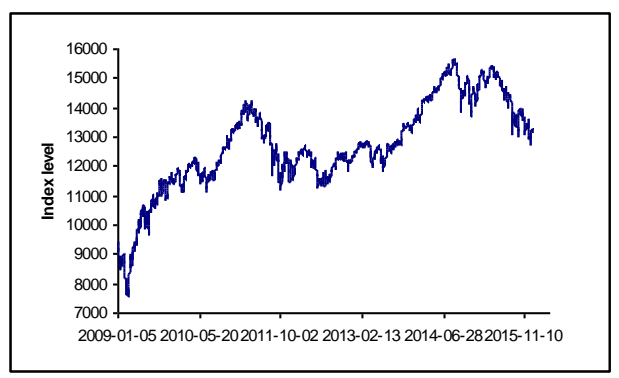

(f)

Source: own elaboration 